ACTA UNIVERSITATIS WRATISLAVIENSIS No 3928

Slavica Wratislaviensia CLXXI • Wrocław 2020

DOI: $10.19195 / 0137-1150.171 .12$

Data przesłania artykułu: 27.09.2018

Data akceptacji artykułu: 1.09.2019

MARIA STRYSZEWSKA

Uniwersytet Wrocławski, Polska

\title{
Przymiotniki odrzeczownikowe w powieści Živko Čingo Големата вода i jej przekładzie na język polski
}

We współczesnym językoznawstwie słowiańskim ważne miejsce zajmują badania konfrontatywne systemów słowotwórczych poszczególnych języków słowiańskich. Potrzeba takich badań wynika z tego, że w leksyku każdego z tych języków zdecydowaną większość stanowią wyrazy motywowane słowotwórczo ${ }^{1}$. Jak wiadomo, badania synchroniczne słowotwórstwa języków słowiańskich zapoczątkowane zostały na przełomie lat pięćdziesiątych i sześćdziesiątych XX wie$\mathrm{ku}^{2}$. W ich wyniku dla większości współczesnych języków słowiańskich powstały opisy słowotwórcze typu akademickiego bądź odpowiadające im rangą opracowania monograficzne. Wyjątkiem jest tu skodyfikowany po drugiej wojnie światowej język macedoński, wciąż wymagający opracowania, które uwzględniałoby osiągnięcia współczesnego słowotwórstwa słowiańskiego. Ponadto znaczna liczba badań dotyczących poszczególnych języków słowiańskich, a także wypracowanie zasadniczo wspólnej metodologii opisu synchronicznego, daje dobrą podstawę do prowadzenia badań synchroniczno-porównawczych (konfrontatywnych).

Zasadniczym przedmiotemartykułu są przymiotnikiodrzeczownikowe, zarówno z niewyspecjalizowanymi semantycznie formantami -ски, -ов/-ев, -ен w języku macedońskim oraz -ski, -owy, -ny w języku polskim, będące jednocześnie podstawowymi wykładnikami derywacji przymiotników odrzeczownikowych w analizowanych językach, jak i te, którym formant nadaje pewne ogólne znaczenie, na przykład derywaty z sufiksem -ecm, a ich znaczenie w języku macedoń-

${ }^{1}$ M. Dokulil, Teoria derywacji, przeł. z czeskiego A. Bluszcz, J. Stachowski, Wrocław 1979, s. 31 .

${ }^{2}$ Dyskusja na temat zagadnień dotyczących metod badawczych słowotwórstwa synchronicznego języków słowiańskich została zapoczątkowana na IV Zjeździe Slawistów w Moskwie w 1958 roku. 
skim można zdefiniować jako: 'podobny, mający formę do tego, co nazywa wyraz motywujący', na przykład тревест килим — 'dywan, który przypomina trawę', стрелест лист - 'liść, który kształtem przypomina strzałę'. W języku polskim takie znaczenie wyrażane jest formantem -asty/-isty. Podstawą materiałową moich rozważań jest tekst powieści Živko Čingo Wielka woda (Големата вода) ${ }^{3}$ oraz jej przekład na język polski ${ }^{4}$. Derywaty przymiotnikowe zarówno w języku macedońskim, jak i polskim tworzone są od podstaw czasownikowych, przymiotnikowych, przysłówkowych oraz od wyrażeń przyimkowych, ale największą grupę tworzą przymiotniki motywowane rzeczownikami.

Przy ustalaniu kierunku derywacji korzystałam ze Słownika gniazd słowotwórczych ${ }^{5}$ odnośnie do języka polskiego, natomiast do języka macedońskiego, dla którego podobny słownik jeszcze nie powstał, posługuję się głównie parafrazą słowotwórczą.

W tekście macedońskim występują pojedynczo 743 przymiotniki motywowane różnymi częściami mowy. Oprócz przymiotników desubstantywnych, które opiszę bardziej szczegółowo, w tekście pojawiają się przymiotniki utworzone od czasowników, przymiotników, wyrażeń syntaktycznych, przysłówków i liczebników, a także przymiotniki złożone i przymiotniki niemotywowane słowotwórczo. Największą grupę tworzą derywaty odczasownikowe, których w tekście jest 312. Przymiotników niemotywowanych słowotwórczo jest 142, ponadto pojawia się 5 derywatów modyfikacyjnych oznaczających intensywność lub osłabienie cechy, na przykład студеникав, ирвеникав. Wszystkie te przymiotniki zaliczają się do przymiotników jakościowych. Do derywatów odprzymiotnikowych należą także zaprzeczenia utworzone z użyciem prefiksu $\mu$-, które są dość liczną grupą 70 derywatów, na przykład нечист, несреќен, недобар. Oprócz tego w tekście występuje 18 przymiotników motywowanych wyrażeniami syntaktycznymi, na przykład бездомен, претсмртен, 16 przymiotników złożonych, na przykład новодојден, животворен, 4 motywowane przysłówkami (олкав, тогамен), 2 motywowane liczebnikami (единствен, првен).

W tekście polskim występują pojedynczo 784 przymiotniki. Podobniejak w tekście oryginału najwięcej jest derywatów odczasownikowych - 313. Przymiotników niemotywowanych słowotwórczo jest 183, derywatów modyfikacyjnych 15, na przykład malutki, chuderlawy, oraz 74 zaprzeczenia utworzone w sposób prefiksalny, na przykład niemiły, niedobry, nieludzki. Wśród pozostałych derywatów pojawia się 19 przymiotników derywowanych wyrażeniami syntaktycznymi, na przykład przedśmiertny, przedwieczorny, 8 przymiotników złożonych, na przykład stuprocentowy, życiodajny oraz pojedyncze derywaty utworzone od innych części mowy: zaimków (tutejszy), liczebników (jedyny) i przyimków (wewnętrzny).

3 Ž. Čingo, Golemata voda, Skopje 2016.

${ }^{4}$ Ž. Čingo, Wielka woda, przeł. z macedońskiego D. Cirlić-Straszyńska, Warszawa 1984.

${ }^{5}$ Stownik gniazd słowotwórczych wspótczesnego języka polskiego, red. H. Jadacka, M. Skarżyński, t. 1-4, Kraków 2002-2004. 
W tekście macedońskim są 174 przymiotniki desubstantywne, które można podzielić ze względu na charakterystykę słowotwórczą rzeczownika podstawy oraz formant słowotwórczy. Jeśli chodzi o pierwszą klasyfikację, to 125 derywatów utworzonych jest od rzeczowników niemotywowanych, co stanowi ponad $70 \%$ wszystkich derywatów. Jeśli sama podstawa słowotwórcza jest derywatem, to często możliwa jest podwójna motywacja, na przykład болскотна капка 'kropla, która błyszczy' (odczasownikowa) lub 'kropla, która daje blask' (odrzeczownikowa).

Co zaś tyczy się formantów, najliczniej reprezentowane są derywaty z sufiksem -ен i jego wariantami, których w tekście jest 90, a więc ponad połowa. Wśród pozostałych jest 49 przymiotników z sufiksem -ски i jego rozszerzeniami oraz mniej liczne klasy derywatów: 6 z sufiksem -ов/-ев, 7 z sufiksem -лив, 7 z sufiksem -есm, 4 z sufiksem - $а в, 3$ z sufiksem - $u н, 2$ z formantem paradygmatycznym, 2 z sufiksem -овит oraz pojedyncze przymiotniki z formantami -иран, -осан, -ив, -ат.

Dla porównania, w analizowanym przeze mnie równolegle materiale słownikowym (na podstawie sześciotomowego słownika Толковен речник на македонскиот јазик ${ }^{6}$ ) ponad połowa to derywaty z formantem -ски i jego wariantami - 52\%, na drugim miejscu jest sufiks $-e \mu$, który tworzy $32 \%$ wszystkich przymiotników, derywatów z sufiksem -ов/-ев jest niecałe 5\%, natomiast derywaty z pozostałymi sufiksami, w tym -есm, -лив, - $а в,-и н$ czy formantem paradygmatycznym — łącznie około $10 \%$ analizowanego materiału.

W polskim przekładzie powieści Големата вода występuje 167 przymiotników desubstantywnych. Jeśli chodzi o podstawy słowotwórcze derywatów, to stosunek rzeczowników motywowanych do niemotywowanych wygląda podobnie jak w tekście oryginału — ponad dwie trzecie rzeczowników podstawy to wyrazy niemotywowane słowotwórczo.

Najliczniejsze w tekście są przymiotniki z sufiksem -ny i jego wariantami (z wyjątkiem sufiksów -alny oraz -any, które tworzą oddzielne klasy) i jest ich łącznie 70. Wśród pozostałych klas jest 28 derywatów z formantem -owy, $22 \mathrm{z}$ formantem -ski, $10 \mathrm{z}$ formantem paradygmatycznym, $10 \mathrm{z}$ formantami -isty/ -asty, $7 \mathrm{z}$ formantem -liwy, po $3 \mathrm{z}$ formantami -any oraz -czy, po $2 \mathrm{z}$ formantami -aty/-owaty oraz -ki oraz pojedyncze przymiotniki z formantami -awy, -iny, -iwy, -ty oraz $-c y$.

Także tutaj widoczne są różnice w odniesieniu do materiału słownikowego ${ }^{7}$, w którym $45 \%$ to derywaty $\mathrm{z}$ formantem -owy, 33\% z formantem -ny oraz jego wariantami, $10 \%$ to derywaty $\mathrm{z}$ formantem -ski i jego wariantami, pozostałe klasy — łącznie $12 \%$ całego materiału.

Wszystkie przymiotniki desubstantywne należą do przymiotników relacyjnych, a doprecyzowanie ich znaczenia możliwe jest jedynie w konkretnym kontekście. W związku z tym do opisu konfrontatywnego interesujących mnie języków wyko-

\footnotetext{
${ }^{6}$ Tolkoven rečnik na makedonskiot jazik, red. K. Koneski, t. 1-6, Skopje 2003-2014.

${ }^{7}$ Uniwersalny stownik języka polskiego, red. S. Dubisz, t. 1-4, Warszawa 2003.
} 
rzystuję model opisu zaproponowany przez Krystynę Kallas w Gramatyce wspótczesnego języka polskiego. Morfologia ${ }^{8}$. Model oparty jest na relacjach semantycznych rzeczownika będącego podstawą słowotwórczą przymiotnika oraz rzeczownika przez ten przymiotnik określanego. Autorka wymienia następujące relacje:

1. SUB - użycia subiektowe, w których rzeczownik podstawy nazywa subiekt, a rzeczownik określany czynność przy niewyrażonym predykacie; relacje subiektowe w tekście macedońskim tworzą przymiotniki z sufiksem -ен: народно творештво, oraz -ски: женска работа, natomiast w tekście polskim -ny: sроteczne uznanie, -owy: walki klasowe, -cy: kobiecy nawyk oraz z formantem paradygmatycznym: pajęcze sieci.

2. OB - użycia obiektowe, w których podstawa przymiotnika nazywa obiekt, a rzeczownik określany może pełnić inne dowolne funkcje; w tekście macedońskim relacje te tworzą przymiotniki z sufiksem -ски: оперски пејач oraz -ен: држсавни празници, w języku polskim zaś -ny: komisja egzaminacyjna oraz -owy: śpiewak operowy.

3. POSS - użycia posesywne, czyli dzierżawcze. W tym wypadku podstawa przymiotnika nazywa posiadacza, a rzeczownik określany — posiadany przez niego obiekt; relacje te $\mathrm{w}$ tekście macedońskim tworzą przymiotniki z sufiksami -ски: детско срие, -ен: брачен реквизит, -ин: мајчини очи, z formantem paradygmatycznym: рибји очи, ponadto w języku macedońskim funkcja dzierżawcza cechuje także sufiks - $о в$, wykorzystywany do tworzenia derywatów od nazw własnych: Кејтенов син. W języku polskim relacje posesywne tworzą derywaty z sufiksami -ski: chrześcijańska dusza, -yny: matczyny głos, -ny: rodzinny dom, -czy: pokutnicza dusza, -cy: dziecięca wyobraźnia oraz z formantem paradygmatycznym: kukutcze gniazdo.

4. INSTR - użycia instrumentowe, gdy podstawa przymiotnika nazywa środek czynności, a rzeczownik określany tę czynność lub obiekt przy niewyrażonym predykacie; w żadnym z tekstów nie występują derywaty w użyciu instrumentowym.

5. MAT — użycia materiałowe — taka relacja zachodzi, gdy przymiotnik podstawy nazywa materiał, z którego wykonany jest wytwór nazwany przez rzeczownik określany; w tekście macedońskim relację tę tworzą przymiotniki z sufiksami -ен: златно лажсич, -ов: зеленчукова чорба, w polskim zaś -ny: jedwabne pończochy, -owy: zupa jarzynowa, -any: blaszany drogowskaz.

6. RES - użycia wskazujące na wytwór - jest to relacja odwrotna do poprzedniej, to znaczy rzeczownik nazywa materiał, a podstawa przymiotnika wytwór. Użycia te nie pojawiają się w żadnym z tekstów.

7. GEN - użycia genetyczne wskazują na relację pochodzenia. Rzeczownik określany nazywa przedmiot, który pochodzi od przedmiotu nazwanego przez rzeczownik podstawy; także te relacje nie pojawiają się w żadnym z tekstów.

${ }^{8}$ K. Kallas, Przymiotnik, [w:] Gramatyka współczesnego języka polskiego. Morfologia, red. R. Grzegorczykowa, R. Laskowski, H. Wróbel, Warszawa 1998, s. 485-494. 
8. SING - użycia syngulatywne, to użycia wskazujące na element zbioru, warunkiem zachodzenia takiej relacji jest kolektywne znaczenie rzeczownika określanego. W tekście macedońskim w tym użyciu pojawiają się przymiotniki $\mathrm{z}$ formantami -ички: артистичка трупа, -ен: литературна дружина, w polskim zaś -ski: komisja lekarska, -ny: drużyna gimnastyczna.

9. TOT - użycia przymiotnika wskazujące na całość, którą nazywa podstawa przymiotnika, do części nazwanej rzeczownikiem określanym; relacja ta pojawia się jedynie w tekście macedońskim i tworzy ją przymiotnik z sufiksem -ски: витаминска чорба.

10. PART - użycia partytywne wskazują na relację odwrotną do poprzedniej. Przymiotnik nazywa część całości nazwanej rzeczownikiem. W tekście oryginału relację tę tworzą derywaty z formantami -ски: щаторско крило, -ов: глогов трн, $\mathrm{w}$ tekście przekładu $\mathrm{z}$ formantem -ny w jednym użyciu: promień słoneczny.

11. CHAR-KONKR - użycia charakterystyczno-konkretne są zbieżne z użyciami partytywnymi, w tym jednak wypadku część nazwana podstawą przymiotnika jest cechą dystynktywną, a określane rzeczowniki przede wszystkim należą do kategorii żywotnych; w tekście macedońskim tworzone są przez przymiotniki $\mathrm{z}$ formantami -ен: снежна бура, -ест: грутчест пат, -лив: дожлив ветар, -ав: боцкква жица; w polskim natomiast -ny: ulewny deszcz, -owy: śniegowa chmura, -isty: wyboista droga, -asty: kolczasta gałazka.

12. CHAR-ABSTR — użycia charakterystyczno-abstrakcyjne, w których przymiotnik przypisuje cechę abstrakcyjną przedmiotowi lub czynności nazwanej rzeczownikiem określanym; w tekście macedońskim w takich użyciach występują derywaty z następującymi sufiksami -ски: стилска прилика, -ен: верно куче, -лив: милозлив глас, -ав: ласкава карактеристика, -осан: Кејтен беше ангелосан, -овит: даровито момче, w tekście polskim derywaty z sufiksami -ski: wiejska chusta, -ny: głośny śmiech, -owy: wzorowy uczeń, -liwy: szczéśliwa chwila, -any: świetlana postać, -iwy: prawdziwy przedmiot, a także z formantem paradygmatycznym: światly człowiek.

13. SIMIL - użycia porównawcze, kiedy podstawa przymiotnika stanowi podstawę porównania, a określany rzeczownik jest w tej relacji członem porównywanym; w tekście macedońskim użycia te tworzone są przez przymiotniki z sufiksami -ски: генералско мустаче, -ен: златна шума, -ест: иилесто нозе; w polskim z sufiksami -ski: rajski ogród, -ny: cmentarny spokój, -owy: stalowe pióra, -any: słomiany ogień, -isty: mglisty sen, -asty: spiczasta głowa, -aty: lodowaty deszcz, -awy: krwawy kwiat oraz z formantem paradygmatycznym: złote stońce.

14. ZAKRES - użycia zakresowe, które pełnią jedynie funkcję nominalną i zawężają zakres rzeczownika. Tego typu relację można przedstawić parafrazą: 'ten rzeczownik określany to rzeczownik podstawy i odwrotnie'; w tekście macedońskim relację tę tworzą przymiotniki z sufiksem -ички: фашистички војник oraz -ест: пајажинеста мрежа, w tekście polskim -ski: sklepienie niebieskie, -ny: koszmarny sen, -owy: dowód rzeczowy. 
15. LIMIT - użycia limitujące też zawężają zakres rzeczownika, ale nie odpowiada im wymieniona wcześniej parafraza; przykładami takich użyć w języku macedońskim mogą być: оперски пејач z sufiksem -ski oraz годишно време z sufiksem -ен. W języku polskim tworzą ją derywaty z sufiksami -ski: utwór literacki, -ny: dzień świąteczny, -owy: śpiewak operowy.

16. LOC - użycia lokatywne, miejscowe lub kierunkowe, w których podstawa przymiotnika jest nazwą miejsca (lub kierunku); w tekście macedońskim tworzą je derywaty z sufiksami -ски: планинска чешма oraz -ен: sидни весници; w tekście polskim -ski: górskie źródto, -ny: polna droga oraz -owy: miejscowa prasa.

17. TEMP - użycia temporalne występują, gdy podstawa przymiotnika nazywa odcinek czasu. $W$ języku macedońskim tworzone są przede wszystkim przez derywaty z sufiksem -ски: декемвриска ноќ oraz -ен: неделно утро, w języku polskim głównie z sufiksem -ny: jesienny bieg, a także -owy: zimowy dzień.

18. CZYN — ostatnia grupa odnosi się do przymiotników będących nazwami czynności, procesów lub stanów, do których według autorki należą także zjawiska atmosferyczne ${ }^{9}$. W tekście macedońskim należą do niej przymiotniki z formantem -ен: бурен ден, w polskim zaś -ny: śnieżny dzień oraz -owy: deszczowy dzień.

Pojedyncze derywaty tworzą więcej niż jedną relację semantyczną w zależności od określanego przez nie rzeczownika. Przymiotnik златен pojawia się w użyciu materiałowym, na przykład златно лажиче ‘łyżeczka zrobiona ze złota' oraz porównawczym, na przykład златно соние 'słońce w kolorze złotym, przypominającym złoto'.

Bywa także, że jedno i to samo użycie kontekstowe można przypisać do dwóch i więcej relacji semantycznych. Dotyczy to między innymi sytuacji, gdy rzeczownik określany nazywa część ciała ludzkiego lub zwierzęcego, na przykład мајчински очи to jednocześnie relacja posesywna i relacja całości do części, a więc 'oczy, które są częścią matki'. Częściowo zbieżne mogą być także relacje charakterystyczno-konkretna i partytywna, wyboista droga to również 'droga składająca się z wybojów'. Оперски пејач może być użyciem obiektowym, jako 'śpiewak, który śpiewa operę' lub lokatywnym, 'który śpiewa w operze', komisja egzaminacyjna jako 'komisja, która przeprowadza egzamin', to jednocześnie użycie obiektowe i czynnościowe przy tej samej parafrazie. Jak zatem wynika z powyższej analizy, granice między poszczególnymi relacjami są nieostre.

Najbardziej produktywne typy słowotwórcze to derywaty z sufiksami $-e H \mathrm{w}$ języku macedońskim oraz -ski, -ny, -owy w języku polskim. Zgodnie z założeniami sufiksy te są wielofunkcyjne i tworzą większość z omówionych relacji semantycznych. Trzeci z podstawowych wykładników derywacji przymiotników odrzeczownikowych w języku macedońskim, sufiks -oв, wykazuje tendencję do specjalizacji znaczeniowej i jego podstawową funkcją jest wyrażanie dzierżawczości.

${ }^{9}$ Ibidem, s. 493. 


\section{Bibliografia}

\section{Literatura podmiotu}

Čingo Ž., Golemata voda, Skopje 2016.

Čingo Ž., Wielka woda, przeł. z macedońskiego D. Cirlić-Straszyńska, Warszawa 1984.

\section{Literatura przedmiotu}

Dokulil M, Teoria derywacji, przeł. z czeskiego A. Bluszcz, J. Stachowski, Wrocław 1979.

Gramatyka wspótczesnego języka polskiego. Morfologia, red. R. Grzegorczykowa, R. Laskowski, H. Wróbel, Warszawa 1998.

Grzegorczykowa R., Puzynina J., Problemy ogólne stowotwórstwa, [w:] Gramatyka wspótczesnego języka polskiego, red. R. Grzegorczykowa, R. Laskowski, H. Wróbel, Warszawa 1998.

Kallas K., Przymiotnik, [w:] Gramatyka współczesnego języka polskiego. Morfologia, red. R. Grzegorczykowa, R. Laskowski, H. Wróbel, Warszawa 1998.

Koneski B., Gramatika na sovremeniot makedonski literaturen jazik, Skopje 1976.

Koneski K., Zvoroobrazuvan̂eto vo sovremeniot makedonski jazik, Skopje 1995.

Słownik gniazd słowotwórczych współczesnego języka polskiego, red. H. Jadacka, M. Skarżyński, t. 1-4, Kraków 2002-2004.

Tolkoven rečnik na makedonskiot jazik, red. K. Koneski, t. 1-6, Skopje 2003-2014.

Uniwersalny stownik języka polskiego, red. S. Dubisz, t. 1-4, Warszawa 2003.

Urban M. Współczesne przymiotniki odrzeczownikowe z wybranymi formantami sufiksalnymi, Toruń 2006.

Waszakowa K., Stowotwórstwo wspótczesnego języka polskiego. Rzeczowniki z formantami paradygmatycznymi, Warszawa 1993.

\section{Desubstantive adjectives in the novel Големата вода (Golemata voda) by Zivko Chingo and its translation into Polish}

\section{Summary}

The article is devoted to the issue of the derivation of denominative adjectives in Macedonian and Polish on the basis of the novel Големата вода (Golemata voda) by Zivko Chingo and its translation. The aim of the article is to indicate the similarities and differences in this scope with regard to both languages. The studied derivatives have been described in accordance with the model adopted by the authors of Gramatyka wspótczesnego języka polskiego. Morfologia (Contemporary Polish Grammar. Morphology), in which the starting point is their contextual significance, and therefore the semantic relationship of the derivative with the noun determined by it.

174 derivatives in Macedonian and 167 in Polish have been analysed and described. In accordance with the assumptions in both languages, derivatives together with basic formatives: -ski, -owy, -ny for the Polish language and -ски, -ов, -ен (-ski, -ov-, -en) for the Macedonian language form the majority of semantic relations, and hence can be considered as multifunctional. In both texts the derivatives with these formatives are the most frequent. Adjectives with other suffixes appear less frequently in the text, and the formatives themselves tend to be of semantic specialization.

Keywords: adjectives, desubstantive adjectives, derivation, comparative grammar, contrastive grammar

Slavica Wratislaviensia 171, 2020

(C) for this edition by CNS 


\section{Прилагательные мотивированные существительными в романе Големата вода Ж. Чинго и его переводе на польский язык}

\section{Резюме}

Данная статья посвящена вопросам, связанным со словообразованием имен прилагательных от имён существительных в македонском и польском языках на материале романа Голема$m a$ вода Ж. Чинго и её перевода на польский язык. Целью исследования является выявление сходств и различий в анализированной области в обоих языках. Все дериваты были описаны по модели принятой авторами академической грамматики современного польского языка Gramatyka wspótczesnego języka polskiego. Morfologia (Грамматика современного польского языка. Морфология), в которой отправной точкой является значение данных примеров в зависимости от контекста, т. е. семантическая связь деривата с описываемым существительным.

Анализу были подвержены и описаны 174 примера на македонском языке и 167 примеров на польском языке. Согласно предположениям в обоих языках дериваты с основными суффиксами, т. е. -cкu, -ов, -ен в македонском и $-s k i,-o w y,-n y$ в польском создают большинство из анализированных семантических связей и, следовательно, их можно назвать многофункциональными. Они также выступают в обоих текстах чаще других примеров. Имена прилагательные, образованные с помощью других суффиксов, появляются реже и показывают тенденцию к семантической специализации.

Ключевые слова: имя прилагательное, словообразование, деривация, сравнительная грамматика

Slavica Wratislaviensia 171, 2020

(C) for this edition by CNS 